Research Article

Human and Medical Genetics

\title{
Alpha thalassemia and alpha-MRE haplotypes in Uruguayan patients with microcytosis and hypochromia without anemia
}

\author{
Ana María Soler ${ }^{1}$, Bruna Facanali Piellusch ${ }^{2}$, Lorena da Silveira ${ }^{1}$, Gisele Audrei Pedroso² ${ }^{2}$ Pablo López ${ }^{3}$, \\ Enrique $\mathrm{Savio}^{4}$, María de Fatima Sonati ${ }^{2}$ and Julio da Luz ${ }^{1}$ (D) \\ ${ }^{1}$ Universidad de la República (UdelaR), Centro Universitario Regional (CENUR) Litoral Norte, \\ Departamento de Ciencias Biológicas, Laboratorio de Genética Molecular Humana, Salto, Uruguay. \\ ${ }^{2}$ Universidade Estadual de Campinas (UNICAMP), Faculdade de Ciências Médicas, Departamento de \\ Patología Clínica, Campinas, SP, Brazil. \\ ${ }^{3}$ Universidad de la República (UdelaR), Facultad de Medicina, Hospital de Clínicas Manuel Quintela, \\ Departamento de Laboratorio de Patología Clínica, Montevideo, Uruguay. \\ ${ }^{4}$ Administración de los Servicios de Salud del Estado (ASSE), Hospital Departamental de Salto, Servicio de \\ Laboratorio Clínico, Salto, Uruguay.
}

\begin{abstract}
Alpha thalassemia is the most common genetic disorder across the world, being the $\alpha-3.7$ deletion the most frequent mutation. In order to analyze the spectrum and origin of alpha thalassemia mutations in Uruguay, we obtained a sample of 168 unrelated outpatients with normal hemoglobin levels with microcytosis and hypochromia from two cities: Montevideo and Salto. The presence of $\alpha$-thalassemia mutations was investigated by gap-PCR, restriction endonucleases analysis and HBA2 and HBA1 genes sequencing, whereas the alpha-MRE haplotypes were investigated by sequencing. We found 55 individuals $(32.7 \%)$ with $\alpha$-thalassemia mutations, 51(30.4\%) carrying the $-\alpha^{3.7}$ deletion, one with the $-\alpha^{4.2}$ deletion and three having the rare punctual mutation HBA2:C.-59C>T. Regarding alpha-MRE analysis, we observed a significant higher frequency of haplotype $D$, characteristic of African populations, in the sample with the $-\alpha^{3.7}$ deletion. These results show that $\alpha$-thalassemia mutations are an important determinant of microcytosis and hypochromia in Uruguayan patients with microcytosis and hypochromia without anemia, mainly due to the $-\alpha^{3.7}$ deletion. The alpha-MRE haplotypes and the $\alpha$-thalassemia mutations spectrum suggest a predominant, but not exclusive, African origin of these mutations in Uruguay.
\end{abstract}

Keywords: Alpha-thalassemia, alpha-MRE, microcytosis, hypochromia, Uruguay.

Received: October 30, 2020; Accepted: Februay 10, 2021.

\section{Introduction}

$\alpha$-thalassemia is the most common genetic disorder across the world. It is mainly caused by deletions of one $(-\alpha)$ or both (--) HBA genes of the $\alpha$-globin gene cluster, although small deletions or point mutations also contribute to the $\alpha$-thalassemia mutations spectrum (Foglietta et al., 1996; Huisman et al., 1998; Steinberg et al., 2001).

The absence $\left(\mathrm{a}^{0}\right.$-thalassemia) or reduction $\left(\mathrm{a}^{+}-\right.$ thalassemia) of $\alpha$-globin synthesis produces an imbalance between a and b-globin chains. This imbalance results in a deficient synthesis of hemoglobin in erythroid cells, causing microcytosis (reduction of mean corpuscular volume, MCV) and hypochromia (reduction of mean corpuscular hemoglobin, $\mathrm{MCH}$ ). Microcytosis and hypochromia with normal levels of $\mathrm{HbA} 2$ can also be due to iron deficiency or anemia of chronic disease (Weatherall and Clegg, 1981; Weiss and Goodnough, 2005).

Send correspondence to Julio da Luz. Universidad de la República (UdelaR), Centro Universitario Regional (CENUR) Litoral Norte, Departamento de Ciencias Biológicas, Laboratorio de Genética Molecular Humana, Rivera 1350, 50000, Salto, Uruguay. E-mail: jdal@fmed.edu.uy.
Hematological alterations depend on the number of $\alpha$-globin genes affected (Steinberg et al., 2001). They range from almost asymptomatic or mild microcytic anemia in individuals with one or two affected genes to life incompatibility in the case of the hydrops fetalis syndrome due to the loss of the four $\alpha$-globin genes. The consequence of losing or carrying alterations in three genes is the presence of a hemolytic anemia with marked variation in phenotypic expression, characterized by the presence of $\mathrm{H}$ hemoglobin (b4) (Higgs et al., 1989).

$\alpha$-thalassemia reaches high frequencies in regions where malaria is or has been endemic, as in African, Mediterranean basin and Southeast Asian populations (Weatherall and Clegg, 2001). Furthermore, $\alpha$-thalassemia mutations have spread across the world by immigration and slave trade (Isola, 1975; Sans, 1994; Weatherall and Clegg, 2001).

The $\mathrm{a}^{+}$-thalassemia due to a deletion of $3.7 \mathrm{~Kb}\left(-\alpha^{3.7}\right.$ deletion) is the most common cause of $\alpha$-thalassemia, which affects both HBA1 and HBA2 genes, resulting in a single hybrid gene (HBA2-HBA1). Another frequent cause of $\mathrm{a}^{+}-$ thalassemia is the deletion of $4.2 \mathrm{~Kb}\left(-\alpha^{4.2}\right.$ deletion $)$ which deletes the entire HBA2 gene (Higgs et al., 1989; Foglietta et al., 1996). African and some Asian populations present the highest frequencies of $-\alpha^{3.7}$ deletion, while the $-\alpha^{4.2}$ 
deletion is more frequent in Asian populations (Kattamis et al., 1996; Weatherall and Clegg, 2001). Both deletions are also observed in European and Mediterranean populations at variable frequencies. For example, in Sardinian and Cypriot populations the $-\alpha^{3.7}$ deletion frequency is $12.6 \%$ and $14.0 \%$ respectively, whereas in the Basque population it is practically inexistent (Steinberg et al., 2001; Weatherall and Clegg, 2001).

The loss of the two $\alpha$-globin genes in cis results in $\mathrm{a}^{0}$-thalassaemias. In the Mediterranean region, the -- ${ }^{\mathrm{MED}}$ and $-{ }^{20.5}$ deletions are the most frequent mutations, whereas in African populations they are almost absent (Kattamis et al., 1996; Steinberg et al., 2001; Weatherall and Clegg, 2001). On the other hand, the deletion of a pentanucleotide (TGAGG) located at the 5 ' end of the HBA2 gene IVS-I ( $a^{\mathrm{HpHI}}$ a $)$, a point mutation at the initiation codon (ATG-ACG) of the HBA2 gene $\left(\alpha^{\mathrm{Ncol}} \alpha\right)$, as well as a point mutation (ATG-GTG) in the HBA1 gene $\left(\alpha \alpha^{\mathrm{Ncol}}\right)$, are the most common non-deletional mutations of $\alpha$-thalassemia in the Mediterranean region (Higgs et al., 1989; Foglietta et al., 1996; Kattamis et al., 1996; Steinberg et al., 2001).

For a pediatric Uruguayan population, da Luz et al. (2013) previously reported that the estimated incidence of $\alpha$-thalassemia was $3.3 \%$ and that only the $-\alpha^{3.7}$ deletion was observed. The $--^{20.5}$ mutation was observed only in one individual from an enriched sample with microcytosis and hypochromia without iron deficiency and normal levels of $\mathrm{HbA} 2$. Interestingly, the $-\alpha^{3.7}$ deletion was observed mainly in Afro-descendants, classification based on their ancestor's origin (da Luz et al., 2013). Soler et al. (2016) reported for the first time in Latin America the $-\alpha^{5.2}$ deletion, a mutation observed in Greek and Italian populations (Pressley et al., 1980; Fortina et al., 1994).

Previous studies, have shown that the Uruguayan population is tri-hybrid, with a greater genetic contribution of European populations ( $~ 84 \%$, mainly Spaniards and Italians) followed in smaller proportions by Native Americans ( 10\%) and sub-Saharan populations ( $\sim 6 \%$ ) (Sans, 1994; Hidalgo et al., 2005; Sans et al., 2006).

In order to contribute to knowledge of $\alpha$-thalassemia mutations in the Uruguayan population, we analyzed 168 outpatients from Montevideo and Salto (117 and 51 respectively) who showed normal $\mathrm{Hb}$ levels and reduced levels of VCM and MCH. Additionally, to investigate the $-\alpha^{3.7}$ deletion origin, we sequenced the alpha-MRE region in individuals with and without this mutation.

\section{Subjects and Methods}

A total of 168 unrelated individuals among 1 and 84 years old were analyzed, 117 outpatients from Hospital de Clínicas - Universidad de la República (UdelaR), Montevideo and 51 from Hospital Regional Salto - Administración de Servicios de Salud del Estado (ASSE), recruited in 2015. The protocol and procedure employed in this research were in compliance with the Helsinki Declaration. Each subject and the children's parents gave written informed consent to participate in the study.

All individuals present normal levels of $\mathrm{Hb}$ and diminished levels of VCM and MCH. In adults $(\geq 15$ years old) the $\mathrm{Hb}$ levels were $\geq 13 \mathrm{~g} / \mathrm{dL}$ for men and $\geq 12 \mathrm{~g} / \mathrm{dL}$ for women. For both sexes, the VCM and MCH levels were $\leq$ $80 \mathrm{fl}$ and $\leq 27 \mathrm{pg}$ respectively. For individuals between 12 and 15 years old, we considered Hb levels $\geq 12$ and VCM and $\mathrm{MCH}$ levels $\leq 78 \mathrm{fl}$ and $\leq 26 \mathrm{pg}$ respectively. In children under 12 years old, the levels of $\mathrm{Hb}$ were greater than $11 \mathrm{~g} /$ $\mathrm{dL}$. In the range between $\geq 5$ and $<12$ years old the VCM and $\mathrm{MCH}$ levels were $\leq 77 \mathrm{fl}$ and $\leq 25 \mathrm{pg}$ respectively, whereas for children under 5 years old $\mathrm{VCM}$ and $\mathrm{MCH}$ levels were $\leq 75 \mathrm{fl}$ and $\leq 24 \mathrm{pg}$ respectively. The $\mathrm{Hb}$ thresholds were according those established by World Health Organization (de Benoist et al., 2008) and the VCM and MCH levels according to Besses et al. (2007).

Genomic DNA was extracted from venous peripheral blood by the salting out method (Miller et al., 1988). All individuals were analyzed for the presence of deletional and non-deletional $\alpha$-thalassemia mutations. The seven most common deletional $\alpha$-thalassemia $\left(-\alpha^{3.7},-\alpha^{4.2},--\right.$ SEA $,--{ }^{\mathrm{FIL}},--^{\mathrm{MED}}$, $-\alpha^{20.5}$, and -- $\left.{ }^{\text {THAI }}\right)$ were checked by multiplex gap polymerase chain reaction (gap-PCR) and agarose gel electrophoresis, according to conditions already described (Tan et al., 2001). The most common non-deletional alpha thalassemia mutations were analyzed by restriction fragment length polymorphism (RFLP) from products amplified by PCR $\left(\alpha^{\mathrm{Hph}} \alpha, \alpha^{\mathrm{Ncol}} \alpha\right.$ and $\alpha \alpha^{\mathrm{Ncol}}$ ) (Hall et al., 1993). Additionally, HBA1 and HBA2 genes were sequenced to analyzes the presence of point mutations or small deletion (Pedroso et al., 2018; Dodé et al., 1990)

The $\alpha$-MRE haplotypes were determined in 157 individuals: 78 individuals with the $-\alpha^{3.7}$ deletion and 79 without $\alpha$-thalassemia mutations. A $310 \mathrm{bp}$ DNA fragment was amplified and sequenced according to conditions previously described (Harteveld et al., 2002). Haplotypes were constructed by assuming that the presence of two common haplotypes was more probable than the combination of one common and one rare haplotype or two rare haplotypes (Long et al., 1990; Castro de Guerra et al., 1997).

\section{Statistical methods}

The genotypic and allelic frequencies were estimated by gene counting. The Hardy-Weinberg equilibrium, the estimation of heterogeneity among the samples by the exact test of population differentiation, and the pairwise $\mathrm{F}_{\mathrm{ST}}$ were evaluated using Arlequin software package v 3.5.2.2 (Excoffier and Lischer, 2010). $\mathrm{F}_{\mathrm{ST}}$ distances between Uruguayan population and other populations were represented in two dimensions by multidimensional scaling (MDS) using the software SPSS 22.0 Data of other populations were obtained from Harteveld et al. (2002), Ribeiro et al. (2003) and from the 1000 Genomes Database.

\section{Results}

$\alpha$-thalassemia mutations were found in 55 individuals (32.7\%). The distribution and frequencies of $\alpha$-thalassemia mutations are showed in Table 1 . The $-\alpha^{3.7}$ deletion was the most frequent mutation observed, 49 individuals heterozygous $-\alpha^{3.7} / \alpha \alpha$ and two homozygous $-\alpha^{3.7} /-\alpha^{3.7}$, whereas the $-\alpha^{4.2}$ deletion was observed in only one individual. Three individuals were heterozygous for the point mutation HBA2: c. $-59 \mathrm{C}>\mathrm{T}$. The mutations distribution and frequencies do not differ 
significantly between the two cities (Montevideo and Salto) analyzed.

The number of different $\alpha$-MRE genotypes and $\alpha$-MRE haplotypes are showed in Table 2 and Table S1. The distribution of $\alpha$-MRE genotypes and $\alpha$-MRE haplotypes were significantly different between individuals with and without the $-\alpha^{3.7}$ deletion $(p<0.05)$.
Multidimensional scaling (MDS) showed the subsample without $-\alpha^{3.7}$ deletion grouped with other Latino-American populations whereas, the sample with the $-\alpha^{3.7}$ deletion was split from these in the second dimension and was found more related to African populations (Figure 1). The lower genetic distances from the subsample without the $-\alpha^{3.7}$ deletion were with Latin-American populations from Peru, Colombia, Puerto

Table 1 - Alpha thalassaemia mutations found in the Uruguayan microcytic and hypochromic sample.

\begin{tabular}{llll}
\hline \multirow{2}{*}{ Genotype } & Montevideo & Salto & Total \\
\cline { 2 - 4 } & $\mathrm{N}(\%)$ & $\mathrm{N}(\%)$ & $\mathrm{N}(\%)$ \\
\hline$\alpha \alpha / \alpha \alpha$ & $77(65.0)$ & $36(70.7)$ & $113(67.3)$ \\
$-\alpha^{3.7 / \alpha \alpha}$ & $36(30.8)$ & $13(25.5)$ & $49(29.2)$ \\
$-\alpha^{3.7 /-\alpha^{3.7}}$ & $1(0.9)$ & $1(1.9)$ & $2(1.2)$ \\
$-\alpha^{4.2} / \alpha \alpha$ & $1(0.9)$ & $1(0.6)$ & $3(1.7)$ \\
HBA2:c.-59C>T & $2(1.7)$ & $1.9)$ & 168 \\
\hline Total & 117 & 51 & \\
\hline
\end{tabular}

Table $2-\alpha$-MRE genotypes in Uruguayan population with and without $-\alpha^{3.7}$ deletion.

\begin{tabular}{|c|c|c|c|c|c|c|c|c|}
\hline \multirow{2}{*}{ Population } & \multicolumn{6}{|c|}{$\alpha$-MRE genotypes } & \multirow{2}{*}{$\mathrm{N}$} & \multirow{2}{*}{$p$} \\
\hline & AA $(\%)$ & $\mathrm{AB}(\%)$ & $\mathrm{AD}(\%)$ & BB (\%) & $\mathrm{BD}(\%)$ & DD (\%) & & \\
\hline$\alpha^{3.7}$ deletion & $23(29.5)$ & $31(39.7)$ & $10(12.8)$ & $5(6.4)$ & $8(10.3)$ & \multirow[t]{2}{*}{$1(1.3)$} & 78 & \multirow{2}{*}{0.0053} \\
\hline$\alpha \alpha / \alpha \alpha$ & $32(40.5)$ & $33(41.8)$ & $1(1.3)$ & $11(13.9)$ & $2(2.5)$ & & 79 & \\
\hline
\end{tabular}

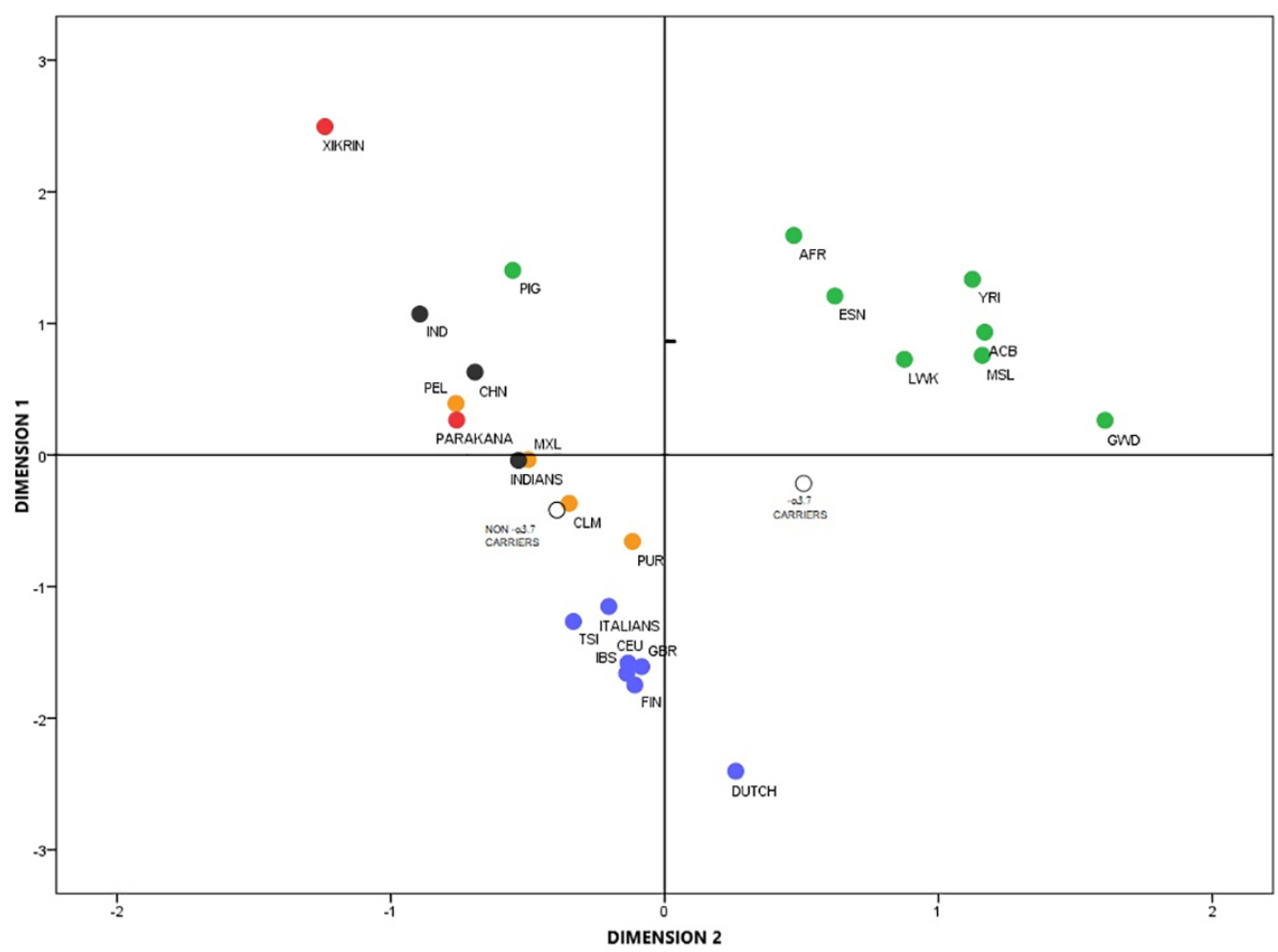

Figure 1 - Multidimensional scaling (MDS) based on pairwise $\mathrm{F}_{\mathrm{ST}}$ genetic distances calculated from alpha-MRE genotypes.

Stress: 0.01390; RSQ: 0.99913. - 33.7 CARRIERS \& NON - $\alpha 3.7$ CARRIERS: Uruguayan populations. Green: African and African derived populations. YRI: Yoruba in Ibadan, Nigeria. ACB: African Caribbeans in Barbados. GWD: Gambian in Western Divisions in the Gambia. MSL: Mende in Sierra Leone. ESN: Esan in Nigeria. LWK: Luhya in Webuye, Kenya. AFR: Bantu-speaking Africans. PIG: Pygmies from the Central African Republic. Orange: Admixed Latin-American populations. PEL: Peruvians from Lima, Peru. PUR: Puerto Ricans from Puerto Rico. CLM: Colombians from Medellin, Colombia. MXL: Mexican Ancestry from Los Angeles USA. Blue: European populations. IBS: Iberian Population in Spain. TSI: Toscani in Italia. CEU: Northern and Western European Ancestry. FIN: Finnish in Finland. ITALIANS. DUTCH. GBR: British in England and Scotland. Black: Asian populations. IND: Indonesians from Java. CHN: Southern Chinese. INDIANS: Andra-Pradesh, India. (1000genomes; Harteveld et al., 2002; Ribeiro et al., 2003). 
Rico and Mexico. However, the subsample with the $-\alpha^{3.7}$ deletion presented the lowest genetic distances with Africans and Afro-Latin-American populations (Table S2).

\section{Discussion}

Our results show that $\alpha$-thalassemia mutations explain an important percentage $(32.7 \%)$ of the microcytosis and hypochromia observed in the Uruguayan population without anemia. Furthermore, the $-\alpha^{3.7}$ deletion was the most frequent mutation. The only non-deletional $\alpha$-thalassemia mutation observed (HBA2 c.-59C $>$ T), affects the last nucleotide of TATA box. This mutation was reported only once in an individual from Australia. In vitro analysis shows a reduction of the transcriptional activity in $53.7 \%$ when compared with the normal allele (HBA2 wild type) (Qadah et al., 2014). In our study, this mutation was observed in three non-related individuals from two different regions of Uruguay. This data suggests a possible founder effect in the Uruguayan population.

The $\alpha$-thalassemia observed frequency $(32.7 \%)$ is similar to previously reported for Rio Grande do Sul, Brazil (31.7\%) (Wagner et al., 2010). However, it is lower than the one reported for Campinas, Southeastern Brazil (49.9\%) (Borges et al., 2001). The high frequency reported for Campinas could be explained by a greater African contribution in this population. Nevertheless, in the Campinas sub-sample selfreported as Caucasian, the $\alpha$-thalassemia frequency was also higher $(41.5 \%)$ than the observed for Rio Grande do Sul and Uruguay (Borges et al., 2001; Wagner et al., 2010; da Luz et al., 2013). We hypothesize that those differences may be due to African genetic ancestry not detected in this subsample. Several studies had showed that Latin-American self-reported as whites present variable levels of African and/or Native American genetic ancestry. For example, in a female population from Brasilia, the percentage of African ancestry in self-reported whites was 17.2\% (Lins et al., 2011). Another explanation may be that the Campinas population self-reported as white presents a greater European contribution from populations with higher $\alpha$-thalassemia frequencies, as South-Italians (Weatherall and Clegg, 2001).

The observed similarity between Rio Grande do Sul and Uruguay is according with the common historical origin from these populations as well as with genetic data showing a high similarity at DNA mitochondrial level (Marrero et al., 2007).

In relation to alpha-MRE haplotypes, the observed differences between the two Uruguayan subsamples (with and without 3.7 deletion) is due to a high frequency of haplotype $\mathrm{D}$ in $\alpha$-thalassemia subsample (Table S1). Haplotype D is characteristic of African populations. It is practically absent in others populations and therefore, is a useful marker for African ancestry (Harteveld et al., 2002). Moreover, the haplotype B frequency for both Uruguayan subsamples was lower than the ones observed for European populations and similar to observed for other admixed Latin-American and Asian populations (Harteveld et al., 2002; Ribeiro et al., 2003). With exception of Pigmies populations, the MDS plot of $\mathrm{F}_{\mathrm{ST}}$ genetic distances calculated from alpha-MRE haplotypes clearly discriminated among African, European and Asian populations. As expected, Native American populations were grouped with Asian populations. Furthermore, admixed
Latin-American populations were placed at an intermediate position between Asian and European populations according to admixture degree. For example, Peruvian and Mexican populations, who have the greater Native American ancestry, were clustered with Asian populations, whereas Colombian and Puerto Rico populations were placed near European populations. Moreover, the Puerto Rico population, which has the greater African ancestry, was displaced towards the African cluster (Rishishwar et al., 2015; Norris et al., 2018). The position of the Uruguayan subsample without the $-\alpha^{3.7}$ deletion next to the Colombian population, agrees with previous reports about the genetic ancestry of these two populations. Similar to reported for a Colombian population from Medellin (Norris et al., 2018), the Uruguayan population shows a greater European genetic ancestry (76.2\%-84\%) followed in smaller proportions by Native Americans $(10 \%$ - 14.7\%) and African ancestry (6\% - 9.1\%) (Sans, 1994; Hidalgo et al., 2005; Sans et al., 2006; Bonilla et al., 2015). However, the Uruguayan $\alpha$-thalassemia subsample is placed near African populations, suggesting a greater African ancestry in this subsample. This is in accordance with previous studies that had shown a greater African ancestry based on self-perception in individuals with the $-\alpha^{3.7}$ deletion (da Luz et al., 2013).

In summary, $\alpha$-thalassemia mutations explain a significant proportion of microcytosis and hypochromia in the Uruguayan population. The alpha-MRE haplotypes and the $\alpha$-thalassemia mutations spectrum observed suggest a predominant, but not exclusive, African origin of the $-\alpha^{3.7}$ deletion in Uruguay.

\section{Acknowledgments}

The authors would like to thank all patients who kindly participated in this study. We also thank Dra. Elza Miyuki Kimura for her technical support. This study received financial support from Coordenação de Aperfeiçoamento de Pessoal de Nivel Superior, Brazil and Universidad de la República, Uruguay (Programa CAPES-UdelaR, grant number no. 2014/00984-3), and Comisión Coordinadora del Interior, Uruguay (CCI-2015).

\section{Conflict of Interest}

The authors report no conflicts of interest that could be perceived as prejudicial to the impartiality of the reported research.

\section{Authors Contributions}

JL and MFS conceived the study. AMS, BFP, LS and GAP conducted the experiments. AMS, BFP and JL analyzed the data, AMS and JL wrote the manuscript. ES and PL collected samples and clinical data: All authors read and approved the final version.

\section{References}

Besses C, Sans-Sabrafén J and Vives JL (2007) Hematología Clínica. 5th edition. Elsevier, Madrid.

Bonilla C, Bertoni B, Hidalgo PC, Artagaveytia N, Ackermann E, Barreto I, Cancela P, Cappetta M, Egaña A, Figueiro G et al. (2015) Breast cancer risk and genetic ancestry: a case-control study in Uruguay. BMC Women's Health 15:11. 
Borges E, Wenning MRSC, Kimura EM, Gervasio SA, Costa FF and Sonati MF (2001) High prevalence of alpha-thalassemia among individuals with microcytosis and hypochromia without anemia. Braz J Med Biol Res 34:759-762.

Castro de Guerra DC, Hutz MH, Bortolini MC and Salzano FM (1997) Beta-globin gene cluster haplotypes in an admixed Venezuelan population. Am J Hum Biol 9:323-327.

da Luz J, Avila A, Icasuriaga S, Gongóra M, Castillo L, Serrón A, Kimura EM, Costa FF, Sans M and Sonati MDF (2013) Frequency and spectrum of hemoglobinopathy mutations in a Uruguayan pediatric population. Genet Mol Biol 36:316-322.

de Benoist B, Cogswell M, Egli I and McLean E (2008) Worldwide prevalence of anaemia 1993-2005. WHO Press, Genève.

Dodé C, Rochette JR and Krishnamoorthy R (1990) Locus assignment of human $\alpha$-globin mutations by selective amplification and direct sequencing. Br J Haematol 76:275-281.

Excoffier L and Lischer HE (2010) Arlequin suite ver 3.5: A new series of programs to perform population genetics analyses under Linux and Windows. Mol Ecol Resour 10:564-567.

Foglietta E, Deidda G, Graziani B, Modiano G and Bianco I (1996) Detection of $\alpha$-globin gene disorders by a simple PCR methodology. Haematologica 81:387-396.

Fortina P, Parrella T, Sartore M, Gottardi E, Gabutti V, Delgrosso K, Mansfield E, Rappaport E, Schwartz E and Camaschella C (1994) Interaction of a rare illegitimate recombination event and Poly A addition site mutation resulting in a severe form of alpha thalassemia. Blood 83:3356-3362.

Hall GW, Thein SL, Newland AC, Chisholm M, Traeger-Synodinos J, Kanavakis E, Kattamis E and Higgs DR (1993) A base substitution $(T \rightarrow C)$ in codon 29 of the $\alpha 2$-globin gene causes $\alpha$ thalassaemia. Br J Haematol 85:546-552.

Harteveld CL, Muglia M, Passarino G, Kielman MF and Bernini LF (2002) Genetic polymorphism of the major regulatory element HS-40 upstream of the human alpha-globin gene cluster. $\mathrm{Br}$ J Haematol 119:848-854.

Hidalgo PC, Bengochea M, Abilleira D, Cabrera A and Alvarez I (2005) Genetic admixture estimate in the Uruguayan population based on the loci LDLR, GYPA, HBGG, GC and D7S8. Int J Hum Genet 5:217-222.

Higgs DR, Vickers MA, Wilkie AO, Pretorius IM, Jarman AP and Weatherall DJ (1989) A review of the molecular genetics of the human $\alpha$-globin gene cluster. Blood 73:1081-1104.

Huisman THJ, Carver MFH and Baysal E (1998) A syllabus of thalassemia mutations. Sickle Cell Anaemia Foundation, Augusta.

Isola E (1975) La esclavitud en el Uruguay desde sus comienzos hasta su extinción (1743-1852). Comisión Nacional de Homenaje del Sesquicentenario de los hechos históricos de 1825; Talleres Gráficos Monteverde y Cia, Montevideo.

Kattamis AC, Camaschella C, Sivera P, Surrey S and Fortina P (1996) Human $\alpha$-thalassemia syndromes: detection of molecular defects. Am J Hematol 53:81-91.

Lins TC, Vieira RG, Abreu BS, Gentil P, Moreno-Lima R, Oliveira RJ and Pereira RW (2011) Genetic heterogeneity of selfreported ancestry groups in an admixed Brazilian population. J Epidemiol 21:240-245.

Long JC, Chakravarti A, Bohem CD, Antonarakis S and Kazazian HH (1990) Phylogeny of human beta-globin haplotypes and its implications for recent human evolution. Am J Phys Anthropol 81:113-130.

Marrero AR, Bravi C, Stuart S, Long JC, Pereira das Neves Leite F, Kommers T, Carvalho CMB, Pena SDJ, Ruiz-Linares A,
Salzano FM et al. (2007) Pre- and post-Columbian gene and cultural continuity: the case of the Gaucho from southern Brazil. Hum Hered 64:160-171.

Miller SA, Dykes DD and Polesky HFRN (1988) A simple salting out procedure for extracting DNA from human nucleated cell. Nucleic Acids Res 16:1215-1216.

Norris ET, Wang L, Conley AB, Rishishwar L, Mariño-Ramírez L, Valderrama-Aguirre A and Jordan IK (2018) Genetic ancestry, admixture and health determinants in Latin America. BMC Genomics 19:75-87.

Pedroso GA, Kimura EM, Santos MNN, Albuquerque DM, Malimpensa D, Jorge SE, Verissimo MPA, Costa FF and Sonati MF (2018) Thalassemia major phenotype caused by HB Zürich-Albisrieden [ $\alpha 2$ 59(E8) Gly > Arg (HBA2:C.178G $>$ C)] in a Brazilian child. Pediatr Blood Cancer 65:e27413.

Pressley L, Higgs DR, Aldridge B, Metaxatou-Mavromati A, Clegg JB and Weatherall DJ (1980) Characterization of a new $\alpha$ thalassemia 1 defect due to a partial deletion of the $\alpha$-globin gene complex. Nucleic Acids Res 8:4889-4898.

Qadah T, Finlayson J, Dennis M and Ghassemifar R (2014) Molecular and cellular analysis of three novel alpha2-globin gene promoter mutations [HBA2:c.-59C $>$ T], [HBA2:c.-81C $>$ A] and [HBA2:c.-91G $>A$ ] reveal varying patterns of transcriptional and translational activities. Pathology 46:46-52.

Ribeiro DM, Figueredo MS, Costa FF and Sonati MF (2003) Haplotypes of $\alpha$-globin gene regulatory element in two Brazilian native populations. Am J Phys Anthropol 12:58-62.

Rishishwar L, Conley AB, Wigington $\mathrm{CH}$, Wang L, ValderramaAguirre A and Jordan IK (2015) Ancestry, admixture and fitness in Colombian genomes. Sci Rep 5:12376.

Sans M (1994) Estudio genético e histórico de la población del departamento de Tacuarembó, Uruguay. PhD Thesis, Universidad de la República, Montevideo.

Sans M, Merriwether DA, Hidalgo PC, Bentancor N, Weimer TA, Franco MHLP, Alvarez I, Kemp BM and Salzano FM (2006) Population structure and admixture in Cerro Largo, Uruguay, based on blood markers and mitochondrial DNA polymorphisms. Am J Hum Biol 18:513-524.

Soler AM, Schelotto M, de Oliveira Mota N, Dorta Ferreira R, Sonati MDF and da Luz JA (2016) The - $(\alpha)(5.2)$ deletion detected in a Uruguayan family: first case report in the Americas. Haemoglobin 40:289-292.

Steinberg MH, Forget BG, Higgs DR and Nagel RL (2001) Disorders of hemoglobin: genetics, pathophysiology, and clinical management. J R Soc Med 94:602-603.

Tan ASC, Quah TC, Low PS and Chong SS (2001) A rapid and reliable 7-deletion multiplex polymerase chain reaction assay for $\alpha$-thalassemia. Blood 98:250-251.

The 1000 Genomes Project Consortium (2015) A global reference for human genetic variation. Nature 526:68-74.

Wagner SC, de Castro SM, Gonzalez TP, Santin AP, Filippon L, Zaleski CF, Azevedo LA, Amorin B, Callegari-Jacques SM and Hutz MH (2010) Prevalence of common $\alpha$-thalassemia determinants in south Brazil: Importance for the diagnosis of microcytic anemia. Genet Mol Biol 33:641-645.

Weatherall DJ and Clegg JG (1981) The thalassaemia syndromes. 3rd edition. Blackwell Scientific Publications, Oxford.

Weatherall DJ and Clegg JB (2001) Inherited haemoglobin disorders: An increasing global health problem. Bull World Health Organ 79:704-712.

Weiss G and Goodnough LT (2005) Anemia of chronic disease. N Engl J Med 352:1011-1023. 


\section{Supplementary material}

The following online material is available for this article:

Table S1 - $\alpha$-MRE haplotypes.

Table S2 - FST genetic distances.
Associate Editor: Filippo Pinto e Vairo

License information: This is an open-access article distributed under the terms of the Creative Commons Attribution License (type CC-BY), which permits unrestricted use, distribution and reproduction in any medium, provided the original article is properly cited. 